\title{
The hypoxia-mimetic agent $\mathrm{CoCl}_{2}$ induces chemotherapy resistance in LOVO colorectal cancer cells
}

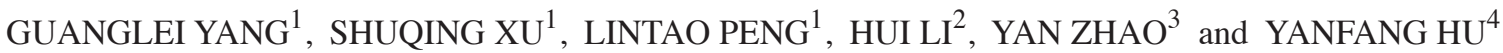 \\ ${ }^{1}$ Department of General Surgery; ${ }^{2}$ The Medical Department, Xingtai People's Hospital Affiliated to \\ Hebei Medical University, Xingtai, Hebei 054031; ${ }^{3}$ Department of Pathogenic Biology, \\ Hebei Medical University, Shijiazhuang, Hebei 050017; ${ }^{4}$ Department of Neurology, \\ Xingtai People's Hospital Affiliated to Hebei Medical University, Xingtai, Hebei 054031, P.R. China
}

Received March 11, 2015; Accepted January 11, 2016

DOI: $10.3892 / \mathrm{mmr} .2016 .4836$

\begin{abstract}
Hypoxia, which is an important factor that mediates tumor progression and poor treatment response, is particularly associated with tumor chemoresistance. However, the molecular mechanisms underlying hypoxia-induced colorectal cancer chemoresistance remain unclear. The present study aimed to explore the mechanism underlying hypoxia-induced chemotherapy resistance in LOVO colorectal cancer cells. LOVO cells were cultured in a hypoxic environment simulated by cobalt chloride $\left(\mathrm{CoCl}_{2}\right)$, which is a chemical inducer of hypoxia-inducible factor- $1 \alpha$ (HIF-1 $\alpha)$. HIF- $1 \alpha$ is a transcription factor that has an important role in tumor cell adaptation to hypoxia, and controls the expression of several genes. Various $\mathrm{CoCl}_{2}$ concentrations are often used to simulate degrees of hypoxia. In the present study, following treatment with $\mathrm{CoCl}_{2}$, an MTT assay was conducted to determine the growth and drug sensitivity of LOVO cells. Reverse transcription-polymerase chain reaction and western blotting were used to detect the mRNA and protein expression levels of HIF- $1 \alpha$ and factors associated with chemotherapy resistance, including multidrug resistance protein (MRP) and multidrug resistant 1 (MDR1), which encodes the major transmembrane efflux transporter P-glycoprotein (P-gp). In addition, the expression levels of apoptosis-related proteins, including B-cell lymphoma 2 (Bcl-2), Bcl-2-associated X protein (Bax) and Bcl-2-associated agonist of cell death (Bad) were detected by western blotting. Flow cytometry (FCM) was used to visually observe Adriamycin (ADR) accumulation and retention, thus analyzing intracellular drug transportation in cells under hypoxic and normoxic conditions. $\mathrm{CoCl}_{2}$-simulated hypoxia was able to inhibit tumor cell proliferation, and upregulate the
\end{abstract}

Correspondence to: Dr Yanfang Hu, Department of Neurology, Xingtai People's Hospital Affiliated to Hebei Medical University, 16 Hong Xing Road, Xingtai, Hebei 054031, P.R. China E-mail:yglhyf@163.com

Key words: hypoxia-inducible factor- $1 \alpha$, cobalt chloride, LOVO colorectal cancer cells, chemotherapy resistance, anti-apoptosis expression levels of HIF-1 $\alpha$, MDR1/P-gp and MRP. In addition, proapoptotic members of the Bcl-2 protein family, Bax and Bad, were downregulated. The anti-apoptotic member Bcl-2 exhibited no significant change in expression, whereas the ratio of Bcl-2/Bax was increased. Results of FCM demonstrated that the intracellular retention of ADR was significantly decreased in the hypoxia group cells. In conclusion, the present study revealed that a $\mathrm{CoCl}_{2}$-simulated hypoxic microenvironment was able to effectively induce chemoresistance and reduce apoptosis in LOVO cells.

\section{Introduction}

Colorectal cancer (CRC) is the third most common type of cancer in men, and the second most common in women (1). Following surgery for the treatment of CRC, chemotherapy is vital, and in patients that lack the opportunity for surgical intervention, chemotherapy is the predominant therapy used to prolong survival. However, sensitivity to chemotherapy varies widely between individuals; according to statistics, $\sim 50 \%$ of patients with CRC succumb to tumor metastasis and recurrence (2).

Hypoxia is a common feature in various types of solid tumor, including CRC. It has previously been reported that hypoxic microenvironments promote the malignant progression of solid tumors (3). Hypoxia-inducible factor 1 (HIF-1) has an important role in the alteration of tumor biology in response to hypoxia. The adaptive response to hypoxia is adjusted by a family of transcription factors;

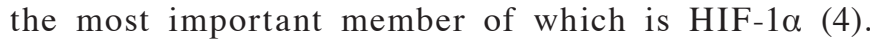
Cobalt chloride $\left(\mathrm{CoCl}_{2}\right)$ has been widely used to simulate hypoxia in in vivo and in vitro studies $(5,6) . \mathrm{CoCl}_{2}$ inhibits the hydroxylation of HIF-1 $\alpha$, thus stabilizing HIF-1 $\alpha$ by preventing it from binding to the von Hippel-Lindau tumor suppressor protein (7-9). In addition, $\mathrm{CoCl}_{2}$ has been shown to activate hypoxia-dependent pathways (10), and is a chemical inducer of HIF-1 (11). In the present study, tumor cells were treated with $\mathrm{CoCl}_{2}$ to stimulate hypoxia. It has previously been reported that hypoxia potentiates tumor resistance to chemotherapy and radiotherapy (12); however, how the hypoxic microenvironment is involved in anticancer drug resistance remains unclear. 
HIF-1 $\alpha$ induces the expression of various genes that are associated with angiogenesis, glucose metabolism, survival and tumor progression $(13,14)$. Multidrug resistance is often caused by overexpression of P-glycoprotein (P-gp) and multidrug resistance protein (MRP). The genes multidrug resistant 1 (MDR1)/P-gp and MRP are able to decrease the efficacy of chemotherapeutic anticancer agents $(15,16)$. The B-cell lymphoma 2 (Bcl-2) family comprises anti-apoptotic and proapoptotic proteins. The Bcl-2 family members Bcl-2, $\mathrm{Bcl}-2$-associated $\mathrm{X}$ protein $(\mathrm{Bax})$ and $\mathrm{Bcl}-2$-associated agonist of cell death (Bad) are considered to be associated with signals of cell survival and damage, and have a critical role in apoptosis. Bcl-2 is an apoptosis suppressor gene, whereas Bax and Bad are apoptosis-inducing genes $(17,18)$. However, the molecular mechanism underlying hypoxia-induced chemoresistance in tumor cells has yet to be fully elucidated. In the present study, the proliferation of LOVO cells and the tumor inhibition ratio (TIR) following treatment with 5-fluorouracil (5-FU) were determined using a 3-(4,5-dimethylthiahiazol-z-y1)-3,5-diphenyte-trazoliumbromide (MTT) assay. Furthermore, reverse transcription-polymerase chain reaction (RT-PCR) and western blotting were used to determine mRNA and protein expression levels, respectively. Flow cytometry (FCM) was used to detect the accumulation and retention of Adriamycin (ADR) under hypoxic and normoxic conditions.

\section{Materials and methods}

Cell lines and cell culture. The LOVO human colorectal cancer cell line was obtained from Peking University Health Science Center (Beijing, China). The cells were cultured in Dulbecco's modified Eagle's medium (DMEM; Gibco; Thermo Fisher Scientific, Inc., Waltham, MA, USA) supplemented with $10 \%$ fetal bovine serum (FBS; Gibco; Thermo Fisher Scientific, Inc.) and antibiotics (1\% penicillin and $1 \%$ streptomycin; North China Pharmaceutical Group Corporation, Shi Jiazhuang, China) at $37^{\circ} \mathrm{C}$ in a humidified incubator containing $5 \% \mathrm{CO}_{2}$.

Chemically induced hypoxia. Hypoxia was achieved by exposing cells cultured in normoxic conditions to $\mathrm{CoCl}_{2}$ (Sigma-Aldrich, St. Louis, MO, USA). Various $\mathrm{CoCl}_{2}$ concentrations are often used to simulate degrees of hypoxia. In the present study, cells were cultured in DMEM with various concentration of $\mathrm{CoCl}_{2}$, or with the same concentration of $\mathrm{CoCl}_{2}$ for various durations. The different concentrations of $\mathrm{CoCl}_{2}$ were obtained by diluting the stock solution $(250 \mu \mathrm{mol} / \mathrm{l})$ in culture medium.

MTT assay for the determination of LOVO cell proliferation. The proliferation of LOVO cells was determined using an MTT assay (BD Biosciences, Franklin Lakes, NJ, USA). The cells were plated in a 96-well plate at a density of $1 \times 10^{4}$ cells/well, in DMEM supplemented with $10 \%$ FBS, and were cultured for $12 \mathrm{~h}$ at $37^{\circ} \mathrm{C}$ with $5 \% \mathrm{CO}_{2}$. Subsequently, the cells were treated with various concentrations of $\mathrm{CoCl}_{2}(100,150,200$ or $250 \mu \mathrm{mol} / \mathrm{l}$ ) for 7 days. Six duplicate wells were set up for each sample. Untreated cells were used as control cells. At the end of the treatment, $20 \mu 1 \mathrm{MTT}(5 \mathrm{mg} / \mathrm{ml})$ was added to the cells, which were incubated for a further $4 \mathrm{~h}$. Dimethyl sulfoxide
(DMSO; $200 \mu \mathrm{l}$ ) was added to each well following removal of the supernatant, and the plate was agitated for 10 min until the crystals had dissolved. Absorbance was measured at $570 \mathrm{~nm}$ using an enzyme-labeling instrument (ELx-800; BioTek, Winooski, VT, USA). The negative control well contained no cells and was considered the zero point of absorbance. Each assay was performed in triplicate. Cell growth graphs were generated with time as the abscissa and absorbance value (mean \pm standard deviation) as the ordinate.

MTT assay for determination of the TIR following treatment with 5-FU. LOVO cells were cultured in various concentrations of $\mathrm{CoCl}_{2}$ to simulate an hypoxic environment as previously described. The TIR following treatment with 5-FU (Sigma-Aldrich) was assessed using an MTT assay. LOVO cells were plated in a 96-well plate at a density of $6 \times 10^{4}$ cells/well, in DMEM supplemented with $10 \%$ FBS, and were cultured for $12 \mathrm{~h}$ at $37^{\circ} \mathrm{C}$ with $5 \% \mathrm{CO}_{2}$. The experimental cells were then treated with various concentrations of $\mathrm{CoCl}_{2}$ $(0,100,150,200$ or $250 \mu \mathrm{mol} / \mathrm{l})$ for $20 \mathrm{~h}$. Five duplicate wells were set up for each sample. The cells not treated with 5-FU were used as the negative control group. The wells that did not contain cells were measured as the blank group. Subsequently, 5-FU was added to the experimental group and blank group cells; each well contained a final concentration of $50 \mathrm{mg} / \mathrm{l}$ 5-FU. Following a $36 \mathrm{~h}$ incubation, $20 \mu \mathrm{l}$ MTT $(5 \mathrm{mg} / \mathrm{ml})$ was added, and the cells were incubated for a further $4 \mathrm{~h}$. DMSO $(200 \mu \mathrm{l})$ was added to each well following removal of the supernatant, and the plate was agitated for $10 \mathrm{~min}$ until the crystals had dissolved. Absorbance was measured at $570 \mathrm{~nm}$ using an enzyme-labeling instrument (EX-800). Each assay was performed in triplicate. The average value was determined for each group: Experimental group average value (EAV), control group average value (CAV) and blank group average value (BAV), these values were used to determine the TIR, as follows: $\mathrm{TIR}=[1-(\mathrm{EAV}-\mathrm{BAV}) /(\mathrm{CAV}-\mathrm{BAV})] \times 100 \%$.

RNA isolation and RT-PCR analysis. LOVO cells were seeded in $6 \mathrm{~cm}$ culture capsules and were treated with a concentration gradient of $\mathrm{CoCl}_{2}(0,50,100,150$ and $200 \mu \mathrm{mol} / \mathrm{l})$ for $24 \mathrm{~h}$. RNA extraction was performed using TRIzol ${ }^{\circledR}$ reagent (Invitrogen; Thermo Fisher Scientific, Inc.), according to the manufacturer's protocol. A total of $5 \mu \mathrm{g}$ RNA was reverse transcribed using the One Step RT-PCR kit (Invitrogen; Thermo Fisher Scientific, Inc.), according to the manufacturer's protocol. The mRNA expression levels of HIF-1 $\alpha$, MDR1 and MRP were determined using a PCR kit (Premix Taq; cat. no. RR901A; Takara Biotechnology Co. Inc., Dailan, China) according to the manufacturer's instructions. The reaction system contained cDNA $(2.5 \mu \mathrm{l})$, Premix Taq $(25 \mu \mathrm{l})$, primers $(2 \mu \mathrm{l})$ and sterile purified water $(\leq 50 \mu 1)$. $\beta$-actin was used as an internal control. PCR primers for each gene were designed based on the mRNA sequence provided by the University of California Santa Cruz database (https://genome.ucsc.edu/) using Oligo6 software (www.oligo.net). All of the primers were provided by Beijing Tsingke Bio Tech, Co., Ltd. (Beijing, China). The primer sequences used were as follows: HIF-1 $\alpha$, forward 5'-GCCGCTGGAGACACAATCAT-3', reverse 5'-GAAGTG GCTTTGGCGTTTCA-3'; MDR1, forward 5'-GGCAAAGAA ATAAAGCGACTG A-3', reverse 5'-GGTGGACAGGCG 
GTGAG-3'; MRP, forward 5'-AGCCAGAAAATCCTCCAC GGT-3', reverse 5'-CATCGCCATCACAGCATTGAC-3'; and $\beta$-actin, forward 5'-CGGGACCTG ACTGACTACCTC-3' and reverse 5'-CTAGAAGCATTTGCGGTGGA-3'. The RT-PCR cycling conditions were as follows: Denaturation for $3 \mathrm{~min}$ at $94^{\circ} \mathrm{C}$, followed by 25 cycles of denaturation for $30 \mathrm{sec}$ at $94^{\circ} \mathrm{C}$, annealing for $30 \mathrm{sec}$ at $55^{\circ} \mathrm{C}, 58^{\circ} \mathrm{C}, 59^{\circ} \mathrm{C}$ and $59^{\circ} \mathrm{C}$ for HIF-1 $\alpha$, MDR1, MRP and $\beta$-actin, respectively, and extension for $10 \mathrm{~min}$ at $72^{\circ} \mathrm{C}$ (Eppendorf 5331 MasterCycler Gradient Thermal Cycler; Eppendorf, Hamburg, Germany). The products were separated by $3 \%$ agarose gel electrophoresis and were visualized with ethidium bromide. The mRNA expression levels were semi-quantified with the aid of computer software (Quantity One 4.4.0; Bio-Rad Laboratories, Inc., Hercules, CA, USA), and the quantity of each transcript was normalized against $\beta$-actin.

Western blot analysis. LOVO cells were treated with $\mathrm{CoCl}_{2}$ $(0,50,100,150$ or $200 \mu \mathrm{mol} / \mathrm{l})$ for $24 \mathrm{~h}$. Protein extraction was conducted as described previously (19). Briefly, the cells were washed with cold phosphate-buffered saline (PBS) $\left(4^{\circ} \mathrm{C}\right)$, were scraped from the surface of the plate into PBS, and were collected by centrifugation at 3,000 $\mathrm{x}$ g for $5 \mathrm{~min}$ at $4^{\circ} \mathrm{C}$. Soluble proteins were extracted with cell lysis buffer containing 1\% NP40, $137 \mathrm{mM} \mathrm{NaCl}, 20 \mathrm{mM}$ Tris base (pH 7.4), $1 \mathrm{mM}$ dithiothreitol, $10 \%$ glycerol, $10 \mathrm{mg} / \mathrm{ml}$ Aprotinin, $2 \mathrm{mM}$ sodium vanadate and $100 \mu \mathrm{M}$ phenylmethylsulfonyl fluoride. Insoluble material was removed by centrifugation at $14,000 \mathrm{x} \mathrm{g}$ for $15 \mathrm{~min}$ at $4^{\circ} \mathrm{C}$. Protein concentrations were determined using the Pierce bicinchoninic acid protein assay kit (Thermo Fisher Scientific, Inc.). The total protein extracts $(2.5 \mu \mathrm{g} / \mu \mathrm{l})$ were separated by $10 \%$ sodium dodecyl sulfate-polyacrylamide gel electrophoresis and were transferred onto nitrocellulose membranes (Bio-Rad Laboratories, Inc.). The membranes were blocked, and were then incubated with primary polyclonal antibodies: Rabbit anti-human HIF-1 $\alpha$ (1:500 dilution; sc-10790), P-gp (1:200 dilution; 8313), MRP (1:200 dilution; sc-13960), Bcl-2 (1:4,000 dilution; sc-783), Bax (1:4,000 dilution; sc-7480), Bad (1:2,000 dilution; sc-783) and $\beta$-actin (1:5,000 dilution; sc-130656) (Santa Cruz Biotechnology, Inc. Dallas, TX, USA) at $4{ }^{\circ} \mathrm{C}$ overnight. After being washed in Tris-buffered saline containing $0.05 \%$ Tween-20, the membranes were incubated with goat anti-rabbit secondary antibody (1:400 dlution; sc-2040; Santa Cruz Biotechnology, Inc.) for $2 \mathrm{~h}$ and were then visualized by chemiluminescence using a Western Luminescent Detection kit (Vigorous Biotechnology, Beijing, China). For quantification, signals were densitometrically normalized to $\beta$-actin using Quantity One image analysis software (version 4.40; Bio-Rad Laboratories, Inc.).

FCM evaluation. Cells were prepared and treated as previously described. ADR (Sigma-Aldrich) produces characteristic fluorescence at an excitation wavelength of $488 \mathrm{~nm}$ and an emission wavelength of $575 \mathrm{~nm}$. The cells were divided into two groups: The experimental group and the negative control group. The experimental group comprised two subgroups: The hypoxia group, cultured in $200 \mu \mathrm{mol} / 1 \mathrm{CoCl}_{2}$ and treated with $5 \mathrm{mg} / \mathrm{l} \mathrm{ADR}$; and the normoxia group cultured in DMEM and treated with $5 \mathrm{mg} / \mathrm{l}$ ADR. The negative control group also comprised two subgroups: The hypoxia group, cultured in $200 \mu \mathrm{mol} / 1 \mathrm{CoCl}_{2}$ only; and the normoxia group cultured in DMEM only. ADR was added to the experimental groups following an $18 \mathrm{~h}$ culture at a final concentration of $5 \mathrm{mg} / 1$, and the cells were treated with ADR for $1.5 \mathrm{~h}$. Subsequently, the cells were washed twice with ice-cold PBS and were collected. FCM (FACSCalibur; BD Biosciences) was used to analyze ADR accumulation. In addition, to measure ADR retention, following collection the cells were resuspended in DMEM medium containing no ADR, and were incubated for $1.5 \mathrm{~h}$. Subsequently, the cells were washed twice with ice-cold PBS, and FCM was used to analyze ADR retention. Data were collected and analyzed using CellQuest software (version 5.1; BD Biosciences). Overlapping images between retention and accumulation were automatically generated by CellQuest software.

Statistical analysis. Each experiment was performed at least three times. All results are presented as the mean \pm standard deviation. Statistical analysis was performed using one-way analysis of variance. All analyses were performed using SPSS software, version 19.0 (SPSS IBM, Armonk, NY, USA). P<0.05 was considered to indicate a statistically significant difference.

\section{Results}

Growth curve of LOVO cells cultured with various concentrations of $\mathrm{CoCl}_{2}$. The growth curve of LOVO cells cultured under normoxic and hypoxic conditions exhibited an ' $S$ ' shape. Compared with the normoxia group, the cells treated with various concentrations of $\mathrm{CoCl}_{2}(100,150$ and $200 \mu \mathrm{mol} / \mathrm{l}$ ) exhibited slow growth during days 1-3.5, and underwent a period of exponential growth and rapid proliferation after 4-7 days (Fig. 1). As $\mathrm{CoCl}_{2}$ concentrations increased the speed of proliferation decreased. Proliferation was inhibited the most following treatment with $250 \mu \mathrm{mol} / 1$ $\mathrm{CoCl}_{2}$, in the growth curve the cells exhibited significant growth inhibition. After 7 days of treatment, a dose-dependent inhibition of cell growth was observed $(\mathrm{P}<0.05)$.

TIR following 5-FU treatment is altered in response to various concentrations of $\mathrm{CoCl}_{2}$. Compared with the normoxia group, following treatment with various concentrations of $\mathrm{CoCl}_{2}(100,150$ and $200 \mu \mathrm{mol} / \mathrm{l})$, LOVO cells acquired resistance against $5-\mathrm{FU}$ as $\mathrm{CoCl}_{2}$ increased. Hypoxia was able to decrease the sensitivity of LOVO cells to 5-FU $(\mathrm{P}<0.05)$, in a dose-dependent manner. However, cells treated with $250 \mu \mathrm{mol} / 1 \mathrm{CoCl}_{2}$ were more sensitive to 5-FU $(\mathrm{P}<0.05)$, as compared with cells in the normoxia group (Fig. 2).

Hypoxia induces overexpression of HIF-1 $\alpha, M D R 1 / P$-gp and $M R P$. Cells were treated with various concentrations of $\mathrm{CoCl}_{2}$ $(0,50,100,150$ and $200 \mu \mathrm{mol} / \mathrm{l})$ for $24 \mathrm{~h}$. Subsequently, mRNA and protein expression levels were detected by RT-PCR and western blot analysis (Fig. 3), with $\beta$-actin as an internal control. The expression levels of HIF-1 $\alpha$, MDR1/P-gp and MRP gradually increased as $\mathrm{CoCl}_{2}$ concentration increased. Therefore, HIF-1 $\alpha$, MDR1/P-gp and MRP were increased in response to $\mathrm{CoCl}_{2}$ in a dose-dependent manner $(\mathrm{P}<0.05)$. 


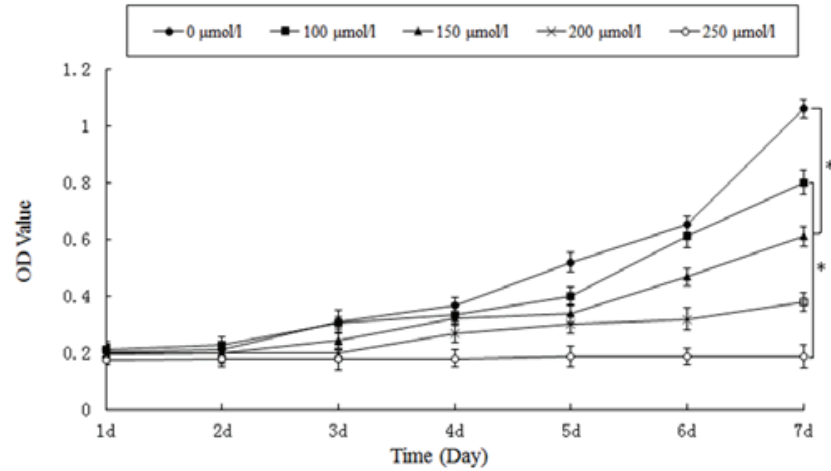

Figure 1. Growth curve of LOVO cells treated with various concentrations of cobalt chloride $\left(\mathrm{CoCl}_{2}\right)$. Cells were treated with $\mathrm{CoCl}_{2}(0,150,200$, 200 or $250 \mu \mathrm{mol} / \mathrm{l})$ for 7 days. Cell proliferation was determined using an 3-(4,5-dimethylthiahiazol-z-y1)-3,5-diphenyte-trazolium bromide assay. Since day 3 , cell proliferation was gradually decreased as $\mathrm{CoCl}_{2}$ increased. Dose-dependent inhibition of cell growth could be observed. Data are presented as the mean \pm standard deviation of three independent experiments. ${ }^{*} \mathrm{P}<0.05$. OD, optical density.

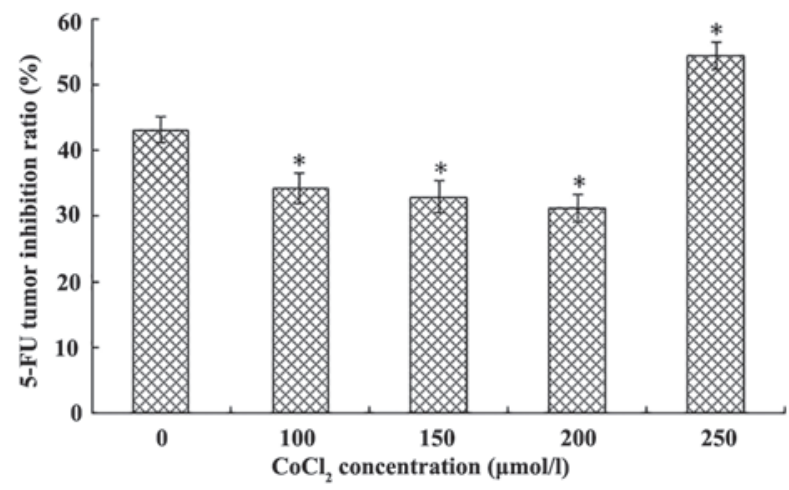

Figure 2. Tumor inhibition ratio following treatment of LOVO cells with 5-fluorouracil (5-FU) and various concentrations of cobalt chloride $\left(\mathrm{CoCl}_{2}\right)$. Tumor inhibition ratio was assessed by 3-(4, 5-dimethylthiahiazol-z-y1)-3,5-diphenyte-trazolium bromide assay, which was performed in triplicate. Following treatment with various concentrations of $\mathrm{CoCl}_{2},(100$, 150 and $200 \mu \mathrm{mol} / \mathrm{l})$ inhibition ratio decreased ( $\mathrm{P}<0.05)$; however, following treatment with $250 \mu \mathrm{mol} / 1 \mathrm{CoCl}_{2}$, the inhibition ratio was increased. Data are presented as the mean \pm standard deviation. ${ }^{*} \mathrm{P}<0.05$, compared with the control group $(0 \mu \mathrm{mol} / \mathrm{l})$.

Hypoxia downregulates Bax and Bad expression. Cells were treated with various concentrations of $\mathrm{CoCl}_{2}(0,50,100,150$ and $200 \mu \mathrm{mol} / \mathrm{l}$ ) for $24 \mathrm{~h}$. Western blot analysis was then performed to detect the expression levels of apoptosis-associated proteins (Bcl-2, Bax and Bad) (Fig. 4). Following treatment with $\mathrm{CoCl}_{2}$, $\mathrm{Bax}$ and $\mathrm{Bad}$ expression levels were gradually decreased in a dose-dependent manner $(\mathrm{P}<0.05)$, whereas no differences in $\mathrm{Bcl}-2$ protein expression were detected $(\mathrm{P}>0.05$; Fig. $4 \mathrm{~A}$ and $\mathrm{B})$. In addition, the ratio of $\mathrm{Bcl}-2 / \mathrm{Bax}$ was increased in a dose-dependent manner ( $\mathrm{P}<0.05$; Fig. 4C).

Hypoxia decreases intracellular retention of ADR. ADR produces characteristic fluorescence at an excitation wavelength of $488 \mathrm{~nm}$ and an emission wavelength of $575 \mathrm{~nm}$. Under hypoxia $\left(200 \mu \mathrm{mol} / 1 \mathrm{CoCl}_{2}\right) \mathrm{FCM}$ was performed to detect the changes in intracellular ADR concentration (Fig. 5). The accumulation and retention of ADR were determined and were used to evaluate changes to intracellular ADR. ADR

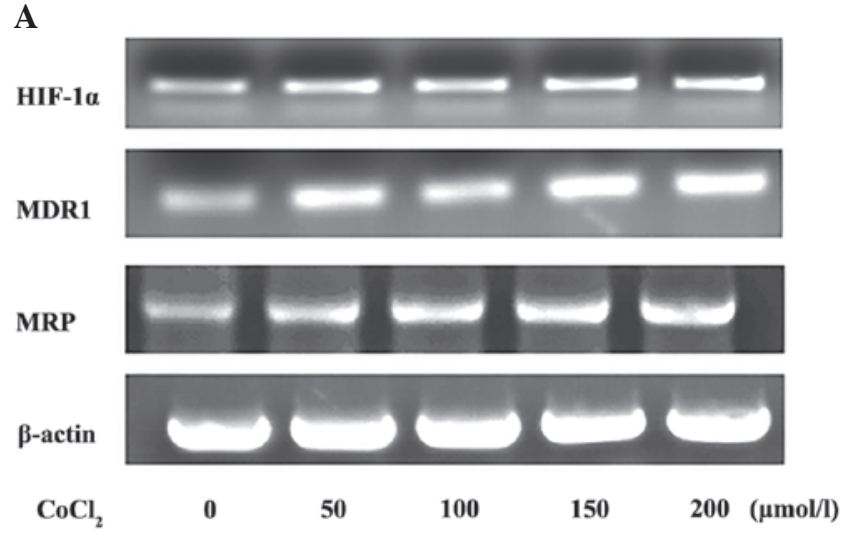

B
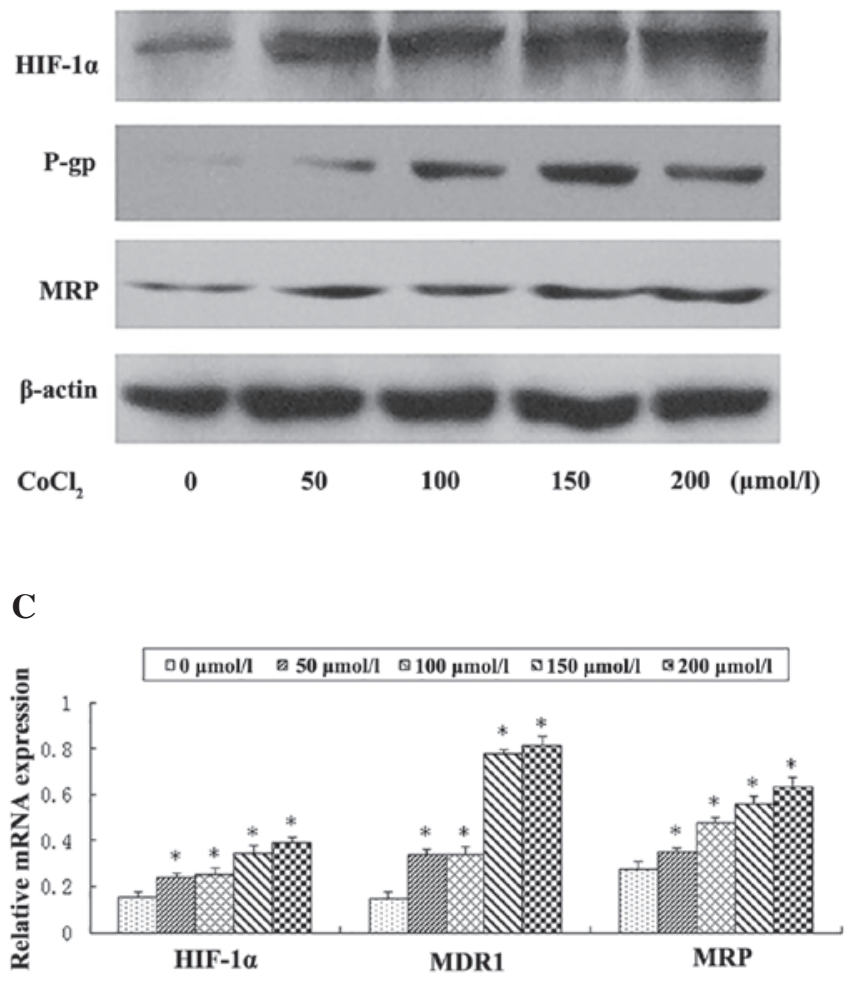

D

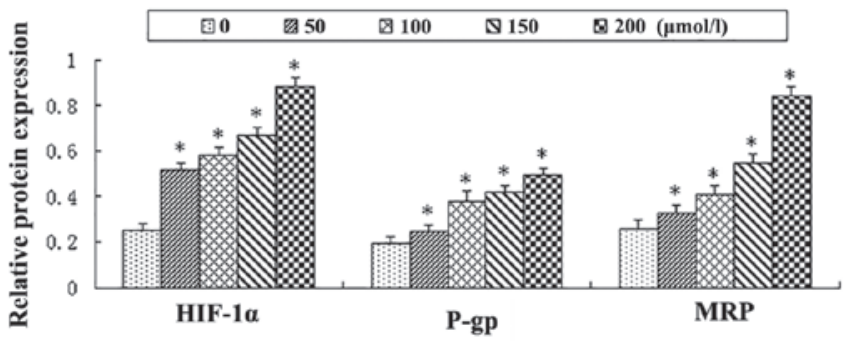

Figure 3. Effects of cobalt chloride $\left(\mathrm{CoCl}_{2}\right)$ on hypoxia-inducible factor (HIF)-1 $\alpha$, multidrug resistant 1 (MDR1)/P-glycoprotein (P-gp) and multridrug resistant protein (MRP) expression in LOVO cells. Cells were pretreated with $\mathrm{CoCl}_{2}(0-200 \mu \mathrm{mol} / \mathrm{l})$ for $24 \mathrm{~h}$. (A) mRNA and (B) protein expression levels of HIF-1 $\alpha$, MDR1/P-gp and MRP were detected by reverse transcription-polymerase chain reaction and western blotting, respectively. Comparison of (C) mRNA and (D) protein expression levels of HIF-1 $\alpha$, MDR1 and MRP between the groups. Following treatment with $\mathrm{CoCl}_{2}$, HIF-1 $\alpha$, MDR1/P-gp and MRP mRNA and protein expression levels were significantly increased in a dose-dependent manner. The experiments were conducted in triplicate. Data are presented as the mean \pm standard deviation. $(\mathrm{n}=3) .{ }^{*} \mathrm{P}<0.05$, compared with the control group $(0 \mu \mathrm{mol} / \mathrm{l})$. 

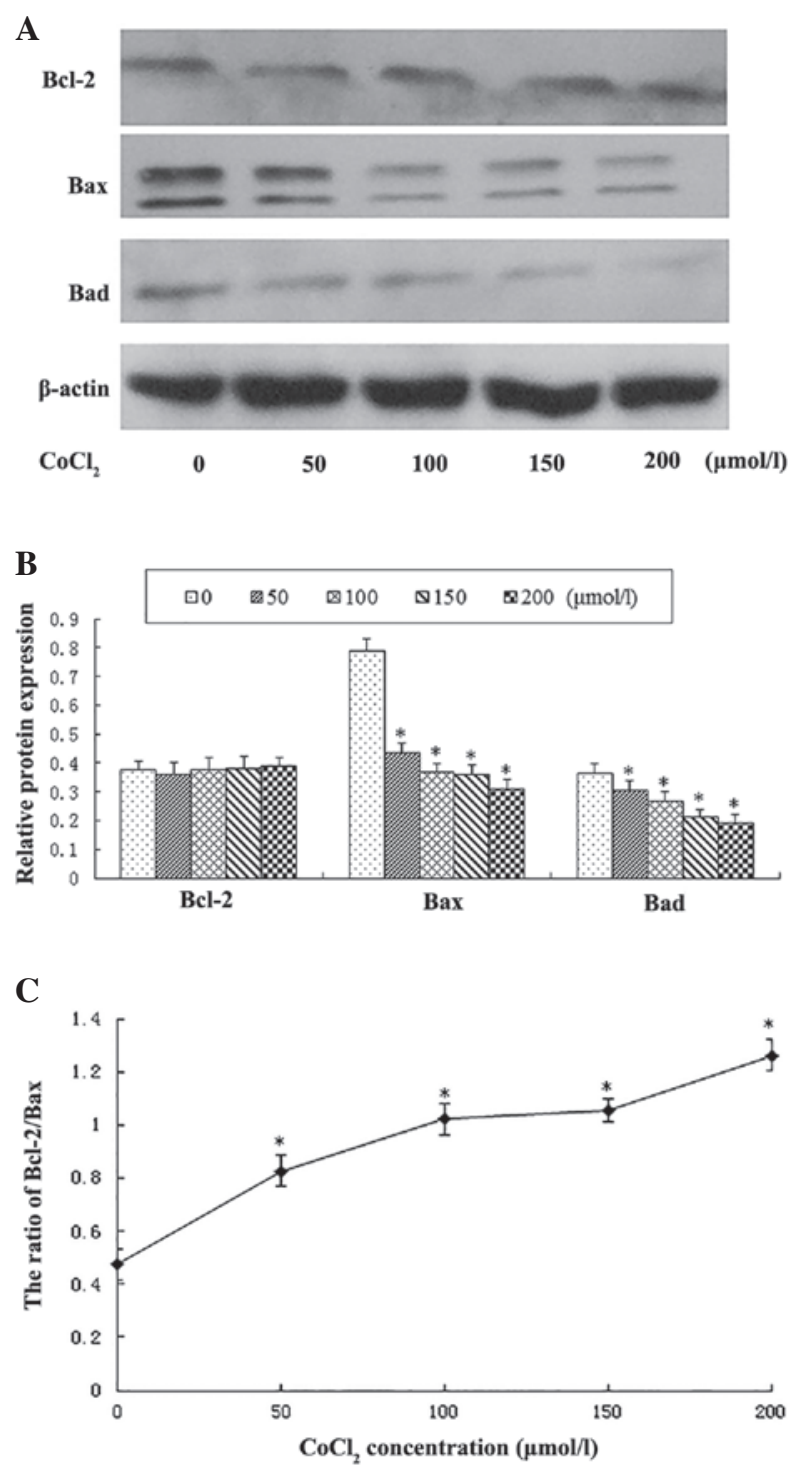

Figure 4. Effects of cobalt chloride $\left(\mathrm{CoCl}_{2}\right)$ on B-cell lymphoma 2 (Bcl-2), Bcl-2-associated $\mathrm{X}$ protein (Bax) and Bcl-2-associated agonist of cell death (Bad) expression in LOVO cells. (A) Cells were pretreated with $\mathrm{CoCl}_{2}$ $(0-200 \mu \mathrm{mol} / \mathrm{l})$ for $24 \mathrm{~h}$, and the expression levels of apoptosis-associated proteins (Bcl-2, Bax and Bad) were detected by western blotting. Variant or cleavage of Bax results in 2 separate protein bands. (B) Comparison of protein expression levels of Bcl-2, Bax and Bad between the groups. The assay was conducted in triplicate. Bax and Bad were significantly decreased in a dose-dependent. (C) Ratio of Bcl-2/Bax was increased in a concentration-dependent manner. Data are presented as the mean \pm standard deviation $(\mathrm{n}=3)$. ${ }^{*} \mathrm{P}<0.05$, compared with the control group $(0 \mu \mathrm{mol} / \mathrm{l})$.

intracellular accumulation exhibited no significant difference between the hypoxia $\left(\mathrm{CoCl}_{2}, 200 \mu \mathrm{mol} / \mathrm{l} ; \mathrm{ADR}, 5 \mathrm{mg} / \mathrm{l}\right)$ and normoxia (DMEM; ADR, $5 \mathrm{mg} / \mathrm{l}$ ) groups. Subsequently, the two groups were cultured for $1.5 \mathrm{~h}$ in fresh DMEM, without ADR. The hypoxia group exhibited a marked decrease in intracellular retention of ADR.

\section{Discussion}

The microenvironment of rapidly growing tumors is associated with increased energy demand and diminished vascular supply, resulting in central areas of prominent hypoxia. The hypoxic phenomenon is considered to be a tumor microenvironment
A

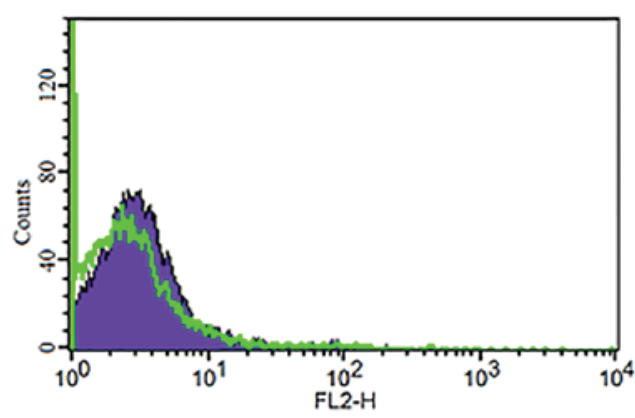

B

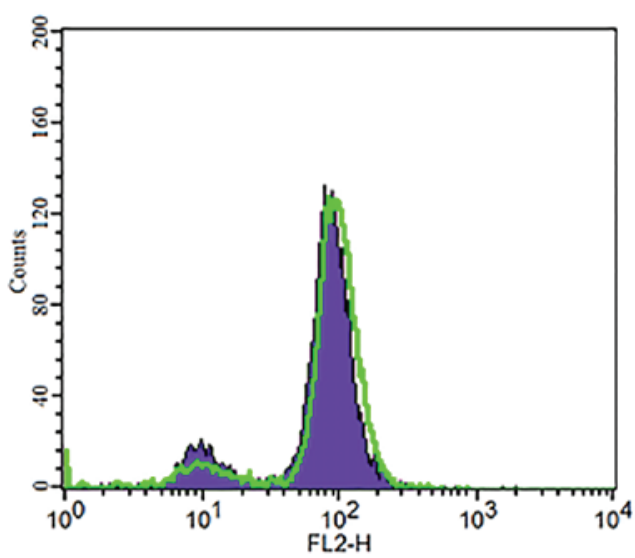

C

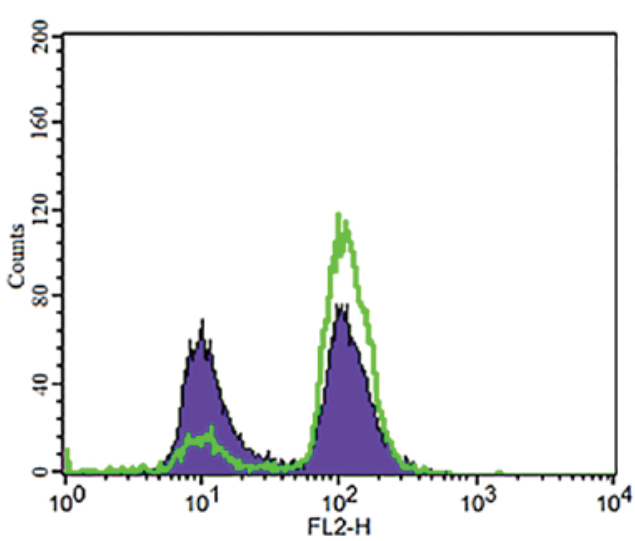

Figure 5. Overlapping images between retention and accumulation. Flow cytometry was used to observe the intracellular accumulation and retention of adriamycin (ADR) in cells treated with cobalt chloride $(200 \mu \mathrm{mol} / 1)$. Green range, normoxia group; purple range, Hypoxia group. (A) Overlapped image of retention and accumulation in the negative control group. (B) Overlapped image of ADR intracellular accumulation in the hypoxia and normoxia groups. (C) Overlapped image of ADR intracellular retention in the hypoxia and normoxia groups.

factor that favors tumor cell survival and resistance to chemotherapy and radiotherapy (20). Experimental and clinical studies have demonstrated that intra-tumor hypoxia may be a key factor in the tumor microenvironment promoting invasive growth and metastasis $(5,21)$. However the molecular mechanisms underlying hypoxia-induced colorectal cancer chemoresistance remain unclear.

$\mathrm{CoCl}_{2}$ has been used as a hypoxia mimic in in vivo and in vitro studies. $\mathrm{CoCl}_{2}$, as a substrate of the ferrochelatase enzyme, can combine with hemoglobin, instead of $\mathrm{Fe}^{2+}$, and cause cells to enter a hypoxic state (22). Hypoxia is a common feature of several types of malignant tumor. HIF-1 $\alpha$ is a major transcription factor and key regulator of adaptive responses 
to hypoxia, including activation of signaling pathways and downstream genes, which promote cell survival and alter the biological characteristics of tumors. HIF-1 $\alpha$ mediates the response to hypoxia by regulating the expression of genes capable of regulating glycolysis, angiogenesis and erythropoiesis, including erythropoietin, vascular endothelial growth factor and pyruvate kinase (23-25). A previous study demonstrated that HIF- $1 \alpha$ is an important regulator of Survivin expression, which may have a potential role as a therapeutic target in cancer (26).

In the present study, LOVO cells were cultured in a hypoxic environment simulated using $\mathrm{CoCl}_{2}$. An MTT assay demonstrated that as $\mathrm{CoCl}_{2}$ concentration increased, proliferation decreased. These results suggested that in order to adapt to the hypoxic environment, cell growth had slowed down. In addition, at a certain extent of hypoxia $(100-200 \mu \mathrm{mol} / 1$ $\mathrm{CoCl}_{2}$ ), the average TIR following treatment with 5-FU was decreased. However, severe hypoxia $(250 \mu \mathrm{mol} / \mathrm{l})$ significantly inhibited growth and increased TIR following treatment with 5-FU. These results indicated that appropriate hypoxia may protect tumor cells; however, severe hypoxia is able to inhibit proliferation, and may increase 5-FU-induced tumor cell apoptosis $(27,28)$.

Under hypoxic conditions, the key molecular player HIF-1 $\alpha$ was upregulated. The present study indicated that mRNA and protein expression levels were markedly increased following treatment with $\mathrm{CoCl}_{2}$ in a dose-dependent manner $(\mathrm{P}<0.05)$, and that the level of hypoxia coincided with the expression of HIF-1 $\alpha$.

Chemotherapy failure remains a major problem in many patients with cancer. Tumor chemoresistance is usually associated with the overexpression of drug-resistance genes. MRP and the MDR1 gene, which encodes the major transmembrane efflux transporter P-gp, are membrane transporter proteins; their function is similar to efflux pumps at cell membranes and they are considered to exert a protective function against the entry of xenobiotics. The overexpression of these genes is the classical mechanism of multidrug resistance in several types of tumor, including lung carcinoma, breast cancer and pancreatic carcinoma (29-31). However, the relationship between LOVO cell hypoxia and chemoresistance has not yet been clearly investigated. The results of the present study demonstrated that under hypoxia HIF-1 $\alpha$ was overexpressed in a dose-dependent manner. In addition, under moderate hypoxia,MDR1/P-gp and MRP were overexpressed in a dose-dependent manner in response to a $\mathrm{CoCl}_{2}$ concentration gradient $(\mathrm{P}<0.05)$. $\mathrm{P}$-gp and MRP are energy-dependent efflux pumps that are responsible for decreases in drug accumulation, which also promote multidrug resistance. In the present study, measurement of ADR accumulation and retention was used to confirm the chemoresistance of cells treated with $\mathrm{CoCl}_{2}$. The FCM results demonstrated that $\mathrm{CoCl}_{2}$-simulated hypoxia affects intracellular ADR concentration in the presence of tumor chemoresistance. This occurred when the intracellular ADR accumulation reached effective concentrations; however, the duration of intracellular ADR retention was the decisive factor in the success of chemotherapy. In addition, the overexpression of MDR1/P-gp and MRP resulted in an increased ability to pump anticancer drugs out of cells; this may be considered an important method by which cancer cells survive anticancer drug treatment under hypoxic conditions. These results suggested that HIF-1 $\alpha$, MDR1/P-gp and MRP may be interactively involved in the occurrence of tumor multidrug resistance.

Whether hypoxia promotes tumor cell apoptosis or decreases apoptosis has yet to be elucidated. Various studies have reached different conclusions. A previous study indicated that overexpression of HIF-1 $\alpha$ could promote downregulation of $\mathrm{BH} 3$ interacting-domain death agonist and/or Bax, thus contributing to etoposide resistance (32). Another study demonstrated that, under hypoxic conditions, HIF- $1 \alpha$ is an important regulator of Survivin, and has a great potential capacity for cancer therapeutics (26). Conversely, HIF-1 has been shown to induce apoptosis, via the stabilization of p53 (33) or the transactivation of BCL2/adenovirus E1B $19 \mathrm{kDa}$ protein-interacting protein 3, which encodes a pro-apoptotic Bcl-2 family member (34). Many contradictory reports involving the role of HIF-1 $\alpha$ in the regulation of apoptosis have emerged in recent years, and the results demonstrate that the effect of tumor cell anti-apoptosis is related to the duration and degree of hypoxia $(35,36)$. In the present study, LOVO cells cultured in an hypoxic microenvironment exhibited reduced apoptosis. This phenomenon may be due to the expression of $\mathrm{Bcl}-2$ family proteins. As $\mathrm{CoCl}_{2}$ concentration increased, the expression of proapoptotic proteins, including Bax and Bad, decreased in the tumor cells; however, the expression of the anti-apoptotic protein Bcl-2 was not significantly altered, thus resulting in a decreased $\mathrm{Bax} / \mathrm{Bcl}-2$ ratio. The ratio of $\mathrm{Bcl}-2 / \mathrm{Bax}$ is usually regarded as a criterion for programmed cell death (37). These results indicated that under hypoxic conditions the downregulation of $\mathrm{Bax}$ and Bad provided a significant survival advantage, since Bax and Bad are suppressors of Bcl-2 and Bcl-extra large (38).

In conclusion, the present study reported that hypoxia altered the phenotype of LOVO colorectal cancer cells. The hypoxic microenvironment was simulated in the present study using the $\mathrm{CoCl}_{2}$ method, and the expression of HIF-1 $\alpha$ was upregulated in a dose-dependent manner. In addition, hypoxia exhibited an inhibitory effect on LOVO cell proliferation, and moderate hypoxia decreased the sensitivity of LOVO cells to 5-FU. In addition, two aspects that may have resulted in hypoxia-induced chemotherapy resistance were identified. Firstly, MDR1/P-gp and MRP were upregulated, which may decrease the retention of chemotherapeutic drugs. Secondly, Bax and Bad expression was downregulated, whereas Bcl-2 expression exhibited no significant change, thus decreasing the Bax/Bcl-2 ratio. Therefore, LOVO cells may escape apoptosis mediated by chemotherapeutic drugs. The hypoxic microenvironment may promote chemoresistance and anti-apoptosis, resulting in greater malignant behavior of tumor cells.

\section{Acknowledgements}

The present study was supported by the Xingtai People's Hospital Affiliated Hebei Medical University, Hebei, China. The authors would like to thank the Molecular Biology Laboratory, Peking University Health Science Center, for equipment support. 


\section{References}

1. Mylonas CC and Lazaris AC: Colorectal cancer and basement membranes: Clinicopathological correlations. Gastroenterol Res Pract 2014: 580159, 2014.

2. Abdalla EK, Adam R, Bilchik AJ, Jaeck D, Vauthey JN and Mahvi D: Improving resectability of hepatic colorectal metastases: Expert consensus statement. Ann Surg Oncol 13: 1271-1280, 2006.

3. Ameri K, Luong R, Zhang H, Powell AA, Montgomery KD, Espinosa I, Bouley DM, Harris AL and Jeffrey SS: Circulating tumour cells demonstrate an altered response to hypoxia and an aggressive phenotype. Br J Cancer 102: 561-569, 2010.

4. Hockel M, Schlenger K, Aral B, Mitze M, Schaffer U and Vaupel P: Association between tumor hypoxia and malignant progression in advanced cancer of the uterine cervix. Cancer Res 56: 4509-4515, 1996.

5. Chu CY, Jin YT, Zhang W, Yu J, Yang HP, Wang HY, Zhang ZJ, Liu XP and Zou Q: CA IX is upregulated in $\mathrm{CoCl}_{2}$-induced hypoxia and associated with cell invasive potential and a poor prognosis of breast cancer. Int J Oncol 48: 271-280, 2016.

6. Dai ZJ, Gao J, Ma XB, Yan K, Liu XX, Kang HF, Ji ZZ, Guan HT and Wang XJ: Up-regulation of hypoxia inducible factor-1 $\alpha$ by cobalt chloride correlates with proliferation and apoptosis in PC-2 cells. J Exp Clin Cancer Res 31: 28, 2012.

7. Semenza GL: Hypoxia-inducible factor 1 (HIF-1) pathway. Sci STKE 2007: $\mathrm{cm} 8,2007$

8. Yuan Y, Hilliard G, Ferguson T and Millhorn DE: Cobalt inhibits the interaction between hypoxia-inducible factor alpha and von Hippel-Lindau protein by direct binding to hypoxia-inducible factor-alpha. J Biol Chem 278: 15911-15916, 2003.

9. Goldberg MA, Gaut CC and Bunn HF: Erythropoietin mRNA levels are governed by both the rate of gene transcription and posttranscriptional events. Blood 77: 271-277, 1991

10. Vengellur A and LaPres JJ: The role of hypoxia inducible factor 1alpha in cobalt chloride induced cell death in mouse embryonic fibroblasts. Toxicol Sci 82: 638-646, 2004.

11. Wang GL and Semenza GL: Desferrioxamine induces erythropoietin gene expression and hypoxia-inducible factor 1 DNA-binding activity: Implications for models of hypoxia signal transduction. Blood 82: 3610-3615, 1993.

12. Ramaekers CH, van den Beucken T, Meng A, Kassam S, Thoms J, Bristow RG and Wouters BG: Hypoxia disrupts the Fanconi anemia pathway and sensitizes cells to chemotherapy through regulation of UBE2T. Radiother Oncol 101: 190-197, 2011

13. Pouysségur J, Dayan F and Mazure NM: Hypoxia signalling in cancer and approaches to enforce tumour regression. Nature 441 437-443, 2006.

14. Harris AL: Hypoxia - a key regulatory factor in tumour growth. Nat Rev Cancer 2: 38-47, 2002.

15. Juliano RL and Ling V: A surface glycoprotein modulating drug permeability in Chinese hamster ovary cell mutants. Biochim Biophys Acta 455: 152-162, 1976.

16. Cole SP, Bhardwaj G, Gerlach JH, Mackie JE, Grant CE, Almquist KC, Stewart AJ, Kurz EU, Duncan AM and Deeley RG: Overexpression of a transporter gene in a multidrug-resistant human lung cancer cell line. Science 258: 1650-1654, 1992.

17. Sasi N, Hwang M, Jaboin J, Csiki I and Lu B: Regulated cell death pathways: New twists in modulation of BCL2 family function. Mol Cancer Ther 8: 1421-1429, 2009.

18. Adams JM and Cory S: The Bcl-2 apoptotic switch in cancer development and therapy. Oncogene 26: 1324-1337, 2007.

19. Bhutia SK, Mallick SK, Maiti S and Maiti TK: Antitumor and proapoptotic effect of Abrus agglutinin derived peptide in Dalton's lymphoma tumor model. Chem Biol Interact 174: 11-18, 2008.

20. Toffoli S and Michiels C: Intermittent hypoxia is a key regulator of cancer cell and endothelial cell interplay in tumours. FEBS J 275 2991-3002, 2008
21. Semenza GL: Targeting HIF-1 for cancer therapy. Nat Rev Cancer 3: 721-732, 2003 .

22. Goldberg MA and Schneider TJ: Similarities between the oxygen-sensing mechanisms regulating the expression of vascular endothelial growth factor and erythropoietin. J Biol Chem 269: 4355-4359, 1994.

23. Forsythe JA, Jiang BH, Iyer NV, Agani F, Leung SW, Koos RD and Semenza GL: Activation of vascular endothelial growth factor gene transcription by hypoxia-inducible factor 1 . Mol Cell Biol 16: 4604-4613, 1996.

24. Gleadle JM and Ratcliffe PJ: Induction of hypoxia-inducible factor-1, erythropoietin, vascular endothelial growth factor, and glucose transporter-1 by hypoxia: Evidence against a regulatory role for Src kinase. Blood 89: 503-509, 1997

25. Mabjeesh NJ and Amir S: Hypoxia-inducible factor (HIF) in human tumorigenesis. Histol Histopathol 22: 559-572, 2007.

26. Wu XY, Fu ZX and Wang XH: Effect of hypoxia-inducible factor 1- $\alpha$ on Survivin in colorectal cancer. Mol Med Rep 3: 409-415, 2010

27. Piret JP, Lecocq C, Toffoli S, Ninane N, Raes M and Michiels C: Hypoxia and $\mathrm{CoCl}_{2}$ protect $\mathrm{HepG} 2$ cells against serum deprivation- and t-BHP-induced apoptosis: A possible anti-apoptotic role for HIF-1. Exp Cell Res 295: 340-349, 2004.

28. Greijer AE and van der Wall E: The role of hypoxia inducible factor 1 (HIF-1) in hypoxia induced apoptosis. J Clin Pathol 57: 1009-1014, 2004.

29. Chen ZJ, Le HB, Zhang YK, Qian LY, Sekhar KR and Li WD: Lung resistance protein and multidrug resistance protein in non-small cell lung cancer and their clinical significance. J Int Med Res 39: 1693-1700, 2011.

30. Linn SC, Pinedo HM, van Ark-Otte J, van der Valk P, Hoekman K, Honkoop AH, Vermorken JB and Giaccone G: Expression of drug resistance proteins in breast cancer, in relation to chemotherapy. Int J Cancer 71: 787-795, 1997.

31. O'Driscoll L, Walsh N, Larkin A, Ballot J, Ooi WS, Gullo G, O'Connor R, Clynes M, Crown J and Kennedy S: MDR1/P-glycoprotein and MRP-1 drug efflux pumps in pancreatic carcinoma. Anticancer Res 27: 2115-2120, 2007.

32. Erler JT, Cawthorne CJ, Williams KJ, Koritzinsky M, Wouters BG, Wilson C, Miller C, Demonacos C, Stratford IJ and Dive C: Hypoxia-mediated down regulation of Bid and Bax in tumors occurs via hypoxia-inducible factor 1-dependent and -independent mechanisms and contributes to drug resistance. Mol Cell Biol 24: 2875-2889, 2004.

33. An WG, Kanekal M, Simon MC, Maltepe E, Blagosklonny MV and Neckers LM: Stabilization of wild-type p53 by hypoxia-inducible factor 1alpha. Nature 392: 405-408, 1998

34. Bruick RK: Expression of the gene encoding the proapoptotic Nip3 protein is induced by hypoxia. Proc Natl Acad Sci USA 97: 9082-9087, 2000.

35. Yin CP, Guan SH, Zhang B, Wang XX and Yue SW: Upregulation of HIF-1 $\alpha$ protects neuroblastoma cells from hypoxia-induced apoptosis in a RhoA-dependent manner. Mol Med Rep 12: 7123-7131, 2015.

36. Wang X, Li J, Wu D, Bu X and Qiao Y: Hypoxia promotes apoptosis of neuronal cells through hypoxia-inducible factor-1 $\alpha$-microRNA-204-B-cell lymphoma-2 pathway. Exp Biol Med (Maywood) 241: 177-183, 2016.

37. Pettersson F, Dalgleish AG, Bissonnette RP and Colston KW: Retinoids cause apoptosis in pancreatic cancer cells via activation of RAR-gamma and altered expression of Bcl-2/Bax. Br J Cancer 87: 555-561, 2002.

38. Letai A, Bassik MC, Walensky LD, Sorcinelli MD, Weiler S and Korsmeyer SJ: Distinct BH3 domains either sensitize or activate mitochondrial apoptosis, serving as prototype cancer therapeutics. Cancer Cell 2: 183-192, 2002. 